AGRICULTURE AND BIOLOGY JOURNAL OF NORTH AMERICA

ISSN Print: 2151-7517, ISSN Online: 2151-7525, doi:10.5251/abjna.2011.2.6.1027.1031

(C) 2011, ScienceHuß, http://www.scihub.org/ABJNA

\title{
Screening and resistance of traditional and improved cultivars of rice to drought stress at Badeggi, Niger State, Nigeria
}

\author{
Gana A.S \\ Department of Crop Production, Federal University of Technology, Minna, Niger State: \\ Nigeria
}

Email- andrewganasaba@yahoo.com Mobile phone number: + 23436373556

\begin{abstract}
.
One hundred and nine rice varieties were screened for drought to select promising varieties for hybridization programs and to be used in drought prone environments. The experiment was conducted in an open screen house in non- rainy days. The test entries were laid out in a randomized complete block design replicated three times. They were planted in a single row of 5 $\mathrm{m}$ each spaced at $20 \times 20 \mathrm{~cm}$. The plants were watered for 21 days before the stress was imposed. Leaf rolling score was taken at 18 days of water stress. Drought score was recorded at 28 days of water stress and 7 days after reapplication of water to access recovery. Result indicated that most varieties had scores between 4-6 that is at susceptible level. Two varieties had score of 2 and eight had score of 3 . At 28 days of stress Danboto had a score of 4 and was better than other varieties. Thirteen entries could be selected for both drought tolerance and recovery. Danboto a local variety was the best variety with drought score of 4 and recovery score of 2. These entries were expected to provide higher yields after severe drought than those entries with high susceptibility.
\end{abstract}

Keywords: drought, variety, recovery, water stress

\section{INTRODUCTION}

Most breeding efforts remain focused on increasing productivity under favourable environments where genetic variance, heritability and therefore breeding progress for grain yield are greatest (Setimela et al., 2004). Trials under random drought conditions are often the only systematic approach exploited to increase yield stability of new crop varieties in drought prone environments (Fukai et al., 1999; Shakhatreh et al., 2001). In rice the effect of drought ranges from slight physiological changes to complete plant desiccation. The magnitude of grain yield losses depends on the duration of the drought, the stage of crop growth and the distribution of rainfall.

Root growth of rice is also reported to be affected by drought stress. Comparing the growth response of two rice varieties, IR5 and Palawan, under upland and irrigated conditions, Hurd (1971) reported that the root development of IR5 was retarded by moisture stress in the upland plot though that of Palawan was less affected. Upland rice varieties, which are more likely to be subjected to drought condition, are tall, low tillering, and the lowland varieties are medium to short in stature and high tillering (Maji, 1994). Chang et al., (1972) reported that leaves and height of lowland varieties are much more reduced than those of upland under drought conditions. Leaves of upland varieties are reported to have higher water content after three hours of sun drying than of lowland types (De Datta et al., 1975).

There are a number of reports on the variability of various components of plant function that contribute to drought tolerance. Blum, (1988) reported genetic variation for leaf water potential in rice. At IRRI, it was reported that 100 crosses made among rice genotypes revealed that leaf rolling was increased when one of the parents involved in the cross was tall upland rice (IRRI, 1976). Singh and Mackil, (1989) in their studies of genetics of leaf rolling in rice under vegetative stage drought stress reported a major gene for leaf rolling.

The ability of the plant to recover after drought was described to be more important than drought tolerance (Maji, 1994). Chang et al., (1974) and De Datta et al., (1975) also considered drought recovery as the determinant of grain yield under stress condition. Also Malabuyoc et al., (1984) stated from their studies that, poor recovery from stress could be a major cause of reduced grain yield. Therefore this study was conducted to select promising drought tolerant cultivars that could be used for hybridization 
programs and for cultivation in drought prone environments.

\section{MATERIALS AND METHOD.}

The experiment was conducted in an open screen house at Badeggi the main Research Station of National Cereals Research Institute (NCRI) in Southern Guinea savanna ecological zone, latitude $9^{0} 045^{1} \mathrm{~N}$ and longitude $6^{0} 07^{1} \mathrm{E}$. The experiment was conducted between November 2002 and January 2003. The seeds were planted on $21^{\text {st }}$ November 2002 by drilling in a row of 1-meter length and spacing of $20 \mathrm{~cm}$. This was done in a randomized complete block design replicated three times. Three checks whose reaction to drought was known were randomized within the three replications. In each replication checks were planted at every $20^{\text {th }}$ entry. The checks were IR 20 (susceptible check), Moroberakan (resistant), and Faro 29 (has intermediate reaction to drought). IR 20 was planted as a spreader row to surround the test entries (Table 1).

The field was irrigated for 21 days after seeding using a rubber hose. Drought was imposed for 28 days. Hand weeding on the plot was carried out twice and urea was applied at the rate of $60 \mathrm{~kg}$ of $\mathrm{N}_{2}$ per hectare.

The plants were scored for leaf rolling at 18 days after stress. Drought reactions were scored at 28 days after stress using 0-9 scale of standard evaluation system for rice (IRRI, 1996). Drought recovery score was taken at seven days after rewatering based on the standard evaluation system for rice. All the varieties with FARO names are improved varieties from National Cereals Research Institute (NCRI), Badeggi, while the TOS lines are landraces collected from International Institute of Tropical Agriculture (IITA). The others were collected from farmers' field.

Table1: Leaf rolling score description

\begin{tabular}{cc}
\hline Scale & Description \\
\hline 0 & Leaves healthy. \\
1 & Leaves starts to fold. \\
3 & Leaves folding (deep V-shaped) \\
5 & Leaves fully cupped (U- shaped) \\
7 & Leaves margins touching (O-shaped) \\
\hline
\end{tabular}

Table 2: Drought score at vegetative stage.

\begin{tabular}{lll}
\hline Scale & Description & Rate \\
\hline 0 & No symptoms & Highly resistant \\
1 & Slight tip drying & Resistant. \\
3 & Tip drying extended to $1 / 4$ length in most leaves & Moderately resistant \\
5 & $1 / 4$ to $1 / 2$ of the leaves fully dried & Moderately susceptible \\
7 & More than $2 / 3$ of all leaves fully dried & Susceptible \\
9 & All plants apparently dead & Highly susceptible \\
\hline
\end{tabular}

\section{RESULTS}

Table 3 is the drought reaction of the check entries. Moroberakan which is a resistant check had the best score of 1 for leaf rolling at 18 days of water stress and a score of 2 at 28 days of water stress. IR 20 which was a susceptible check and had a score of 6 which indicate susceptibility. Results from Table 4 is the leaf rolling score at 18 days of water stress. Most varieties had scores between 4-6 that is at susceptible level. Two varieties had score of 2 and eight had score of 3 . These varieties are moderately resistant at that date. Four varieties were highly susceptible, scores of 8 and 9 . This result showed that none of these varieties were better than the resistant check but 58 of the varieties were better than the susceptible check. Table 5 shows reaction of the entries after 28 days of water stress. Danboto which is a local variety is the only entry with a score of 4 . Sixteen entries had a score of 5 . Most of the TOS lines which are landraces fall into this group. Majority of the varieties had reaction scores of 6 and 7. These shows susceptible reaction. FARO 36 is the only entry with a score of 9 . Moroberakan which is a resistant variety is better than all the entries at 28 days of water stress. In Table 6, reaction of entries when water was reapplied after 7 days, most entries had scores between 4 and 6 that is moderately susceptible to susceptible level. Eight entries had scores of 7 and FARO 36 is the only entry with a score of 8 . Table 7 shows those varieties that had reaction score of 4 and 5 at 28 days of water stress and recovery score after reapplication of water. Thirteen of the varieties belong to this group most of them are landraces. 


\section{AGRICULTURE AND BIOLOGY JOURNAL OF NORTH AMERICA \\ ISSN Print: 2151-7517, ISSN Online: 2151-7525, doi:10.5251/abjna.2011.2.6.1027.1031 \\ (C) 2011, ScienceHuß, http://www.scihub.org/ABJNA}

Table 3: Drought reaction for the checks

\begin{tabular}{lllll}
\hline Varieties & Leaf rolling & $1^{\text {st }}$ drought score & $2^{\text {nd }}$ drought score & $\begin{array}{c}\text { Drought } \\
\text { recovery }\end{array}$ \\
\hline IR 20 Suceptible ( Ck) & 6 & 2 & 6 & 6 \\
Moroberakan Resist (CK) & 1 & 1 & 2 & 3 \\
Faro29 & 7 & 1 & 7 & 6 \\
\hline
\end{tabular}

Table 4: Leaf rolling score at 18 days of water stress.

\begin{tabular}{|c|c|}
\hline Scale & Name of variety \\
\hline 1 & Nill \\
\hline 2 & Shakuyagi, Bisanleyakolo, Bubanfari \\
\hline 3 & Toma, Philiphines, Somazhigi, Gyanako (CH), Ndachelegbo, FARO 23, FARO 15, FARO 33 \\
\hline 4 & $\begin{array}{l}\text { Ebangichi (BA), Gangaza, Mass, Ebangichi (ED), Gabachi, Dokochi, Akpuruku (ND), Jarankuara, Danboto, } \\
\text { Dubbu 2, FARO 12, NCRI 1, FARO 30, FARO 39, FARO 35, FARO 43, FARO 40, FARO 51, FARO } 27 \text {, FARO } \\
\text { 20, TOS } 7730 \text {, TOS } 8089 \text {, TOS } 8091 \text {, TOS } 8189 \text {, TOS } 12462 \text {, TOS } 14519\end{array}$ \\
\hline 5 & $\begin{array}{l}\text { Tomawawagi, Saganuwangi, Ebangichi (KU), Egwazawunkpa (DO), Jufangi, Farosipi, Shagari, Farankaura, } \\
\text { Ebangichi (GZ), Nasara 2, FARO 10, FARO 18, FARO 45, FARO 8, FARO 44, FARO 50, FARO 7, FARO 46, } \\
\text { FARO 19, TOS 9285, TOS } 14499 .\end{array}$ \\
\hline 6 & $\begin{array}{l}\text { Tomako, landachi, Nasara, Finiko, Danmale, Mambachi (KB), Ndawodzufanchi, Bokuchi, Ebangichi (KK), Dubbu } \\
\text { 1, Ndabissangi, Kpuruga, Gbagudu, pasankunya, Ndachele, Egwazanwunkpa(BA), Egwazawunkpa (GZ), } \\
\text { Kparazhikogi, Akpuruka (GZ), FARO 22, FARO 1, FARO 47, FARO 11, FARO 38, FARO 29, FARO 28, FARO } \\
\text { 33, FARO 13, FARO 5, FARO } 37 . \\
\text { Eyewawagi, Nnakashikpanti, Manbechi (ED), Janiri, Manbekochi, Nasara 1, }\end{array}$ \\
\hline 7 & $\begin{array}{l}\text { Mambechi (GZ), FARO 32, FARO 4, FARO 31, HTA 60, FARO 21, FARO 16, FARO 34, FARO } 41 . \\
\text { FARO 48, FARO 17, }\end{array}$ \\
\hline 9 & FARO 2, FARO 36. \\
\hline
\end{tabular}

Table 5: Reaction of the varieties to Drought at 28 of water stress.

\begin{tabular}{|c|c|}
\hline Scale & Name of variety \\
\hline 4 & Danboto (1) \\
\hline 5 & $\begin{array}{l}\text { Toma, Farankuara, Jarankuara, Bubanfari, NCRI1, Faro35, Faro20, Tos7730, Tos8089, Tos8081, } \\
\text { Tos8163, Tos8189, Tos9285, Tos12465, Tos14499, Tos14519.(16) }\end{array}$ \\
\hline 6 & $\begin{array}{l}\text { Saganuwangi, Finniko, Philippines, Gargaza, Mass, Ebangichi(Ed), Jufangi, Fari-sipi, Somazhingi, } \\
\text { Dokochi, Ndawodzufangi, Bokuchi, Gyanako, Shagari, Bisanleyakolo, Ndachelegbo, Dubbu1, Akpuruka, } \\
\text { Ndabisangi, Kpuruka, Pasakunya, Janiri, Manbekochi, Dubbu2, Ndachele, Nasara2, Faro1, Faro4, } \\
\text { Faro31, Faro47, Faro21, Faro10, Faro23, Faro18, Faro45, Faro15, Faro44, Faro50, Faro30, Faro41, } \\
\text { Faro33, Faro7, Faro27, Faro37.(46) }\end{array}$ \\
\hline 7 & $\begin{array}{l}\text { Tomawawagi, Tomako, Danmale, Ladanchi, Egwazawunkpa(Do), Gabachi, Manbechi, Shakuyagi, } \\
\text { Ebangichi(K), Nnakashikpanti, Manbekochi, Gbagudo, Ebangichi, Nasara1, Egwazawunkpa, } \\
\text { Manbechi(Gz), Egwazawunkpa(Gz), Faro26, Faro44, Faro11, Faro12, Faro8, Faro38, Faro29, Faro39, } \\
\text { Faro48, Faro46, Faro13, Faro40, Faro19, Faro5.(31) }\end{array}$ \\
\hline 8 & $\begin{array}{l}\text { Ebangichi(B), Ebangichi(K), Nasara, Gyanako, Eyewawagi, Kparazhikogi, Faro32, Faro17, Faro2, HTA60, } \\
\text { Faro16, Faro34, Faro28.(14) }\end{array}$ \\
\hline 9 & Faro36 (1) \\
\hline
\end{tabular}


Agric. Biol. J. N. Am., 2011, 2(6): 1027-1031

Table 6: Drought recovery seven days after reapplication of water.

\begin{tabular}{|c|c|}
\hline Scale & Name \\
\hline 2 & Danboto \\
\hline 3 & .Nill \\
\hline 4 & $\begin{array}{l}\text { Saganuwangi, Tomako, Toma, Gargaza, Jufangi, Faro-sipi, Shagari, Bisanleyakolo, Ndachelego, } \\
\text { Jarankuara, Ndabisangi, Kpuruga, Janiri, Faro31, Faro10, Faro23, Faro45 Faro12, } \\
\text { Faro38,NCRI1 Faro44, Faro35, Faro33, Faro7, Faro13, Faro37, Faro20, Tos7730, Tos8089, } \\
\text { Tos8163, Tos9285, Tos12465, Tos14519. }\end{array}$ \\
\hline 5 & $\begin{array}{l}\text { Tomawawagi, Ebangichi(Ba), Ebangichi(Ku), Finniko, Philippines, } \\
\text { Gyanako, Pasakunya, Ebangichi(KK), Nnakashikpanti, Akpuruga, Manbekochi, Bubanfari, } \\
\text { Dubbu2, Ndachelegbo,, Faro26, Faro22, Faro18, Faro15, Faro29, Faro43, Faro40, Faro51, } \\
\text { Faro5, Tos14499, }\end{array}$ \\
\hline 6 & $\begin{array}{l}\text { Ladanchi, Gyanakochi, Ebangichi(GB), Egwazawunkpa(Do), Danmale, Ebangichi(Ed), Mass, } \\
\text { Somazigi, Gabachi, Dokochi, Ndawodzufangi, Bokuchi, Eyewawagi, Manbechi(Ed), Dubbu1, } \\
\text { Farankuara, Gbagudo, Dubbu2, Nassara1, Egwazawunkpa(Ba), Nasara2, Manbechi(Gz), } \\
\text { Egwazawunkpa(Gz), Faro17, Faro1, Faro4, Faro47, HTA60, Faro21, Faro16, Faro8, Faro50, } \\
\text { Faro30, Faro39, Faro41, Faro28, Faro48, Faro46, Faro19. }\end{array}$ \\
\hline 7 & Nasara, Manbechi (Kb), Shakuyagi, Ndawodzufanchi, Faro 32, Faro 2, Faro 11, Faro 34, \\
\hline 8 & Faro36. \\
\hline
\end{tabular}

Table 7: Varieties with good score for both drought score at 28 days of stress and drought recovery.

$\begin{array}{lcc}\text { Varieties } & \text { Drought score } & \text { Recovery score } \\ \text { Danboto } & 4 & 2 \\ \text { Toma } & 5 & 4 \\ \text { Jarankaura } & 5 & 4 \\ \text { Faro } 35 & 5 & 4 \\ \text { Tos } 7730 & 5 & 4 \\ \text { Tos } 8081 & 5 & 4 \\ \text { Tos } 8163 & 5 & 4 \\ \text { Tos } 8189 & 5 & 4 \\ \text { Tos } 9285 & 5 & 4 \\ \text { Tos } 12465 & 5 & 4 \\ \text { Tos } 14519 & 5 & 4 \\ \text { Bubanfari } & 5 & 5 \\ \text { Tos } 14499 & 5 & 5\end{array}$

\section{DISCUSSION}

In drought studies leaf rolling, leaf tip burn, which is used to measure drought occurrence were used as an indication of tolerance. Leaf rolling scored at 18 days of stress showed that only few varieties could give a score of 3 . Blum (1988) reported the use of delayed leaf rolling under water stress as important selection criteria for dehydration avoidance. Leaf rolling was considered to be a response to leaf water potential and has been found to correlate with leaf water potential in rice. Delayed leaf rolling was considered as a desirable character in rice (Maji, 1994).

According to Blum (1988), a plant that maintains high leaf water potential will show less leaf rolling. The drought score for the first and the second score showed a score range of $4-9$ at 28 days of water stress. This showed that at 28 days of water stress most of the materials were susceptible to the stress. Chen et al., (1993) in their screening of 2953 
accessions of rice observed that 42 were highly resistant, 79 resistant, 1255 moderately resistant and 1733 susceptible to highly susceptible to drought. The trend in this study at 28 days of water stress is that one variety had a score of $4(0.9 \%), 16$ varieties had moderately susceptible reaction (14.67\%), 76 (70.64\%) had susceptible reaction and 14 (13.76\%) were highly susceptible. Results for the drought recovery investigation showed similar pattern with drought score at 28 days of water stress. Danboto was still the best for the recovery and Faro 36 was the worst for the recovery with a score of 8 (highly susceptible reactions). All the landraces had a score of 5 and $43.12 \%$ of the varieties are at susceptible level. Singh and Mackill, (1988) stated that resistant donors are usually traditional varieties from drought prone environments. Cheng and Wang, (1984) and De Datta et al., (1975) also considered drought recovery as the determinant of grain yield under stress condition. Similarly, Malabuyoc et al., (1984) concluded from their study of four rice lines under soil stress, that poor recovery from stress could be a major cause of reduced grain yield. $14.67 \%$ of these varieties with a score of 5 could be selected for cultivation in drought prone areas. Danboto could be used as a donor gene for drought recovery. Faro 36 is the only variety with a drought recovery score of 8 . The same variety had a score of 9 for drought tolerance. This shows that Faro 36 will give complete yield loss when 28 days of water stress was imposed. Best entries for both drought tolerance and recovery are presented in Table 5. Thirteen entries were selected. Danboto was the best variety with drought score of 4 and recovery score of 2 . These entries were expected to provide higher yields after severe drought than those entries with high susceptibility. Most of these varieties are landraces and local varieties.

\section{REFERENCES}

Blum, A (1988). Plant breeding for stress environments CRC press inc. Florida, USA. PP.43-77.
Chang, T.T.,Loresto, G.C and Tagumpoy, O. (1972) Agronomic and growth characteristics of upland and lowland rice varieties. In: Rice breeding PP 645-601.

Chang, T. T., G. C. Loresto and O. Tagunpay (1974) Screening Rice germplasm for drought resistance. SABRAO J. (6198-16).

Cheng, K. and X. Wang (1984). Study on the indigenous rices in Yunnan and their utilization. Acta agron. Sci. $10(3,4): 163-179 ; 271-280$.

De Delta, S. K., T. T. Chang and S. Yoshida (1975). Drought Tolerance in upland Rice. (In) Major Research in upland rice. IRRI Los Banos Philippines (205) pp 101-116.

Fukai S, Pantuwan G, Jongdee B and Cooper M (1999). Screening for drought resistance in rainfed lowland rice. Field Crop Research 64, 61-74

Hurd, (1971). Can we breed for drought resistance? P7788 (In) K. C. Lawson and J. O. Easton Ed; drought injury and resistance in crops CSSA Crop science society of America spec. pub. 2 madison.

IRRI, (1976). Annual Report for 1975. International Rice Research Institute, Los Banos, Philippines Pp418

Mackil, D.J. W.R. Coffman and D.P. Harrity (1996). Rainfed lowland rice improvement. IRRI, Philippines Pp242

Maji, A.T. (1994): Vegetative stage drought tolerance and agronomic characteristics of Oryza glaberrima accessions. Msc Thesis University of Ibadan Pp156

Malabuyoc, J. A., E. L. Aragon and S. K. De Dalta (1984). Recovery from drought induced desication at vegetative growth stage in direct seeded rain fed Rice. Field crop research Vol. 10, 105-112.

Setimela P.S, Hudson D and Vivek B (2004) Breeding for improved drought tolerance in maize adapted to southern Africa. $4^{\text {th }}$ International Crop Science Congress

Shakhatreh $\mathrm{Y}$, Kafawin $\mathrm{O}$, Ceccarelli $\mathrm{S}$ and Saoub $\mathrm{H}$ (2001). Selection of barley lines for drought tolerance in rainfed areas. Journal of Agronomy and Crop Science 186, 119-127

Singh, B.N. and Mackill D.J. (1998). Genetics of leaf rolling under drought stress. Rice Genetics Newsletter Pp159-166. 